\title{
Inorganic Pyrophosphatase Activity in Cell-free Extracts of Ureaplasma urealyticum
}

\author{
By JOHN W. DAVIS, JR, ${ }^{*}$ IAN S. MOSES, CHRISTOPHER NDUBUKA \\ AND RAFAEL ORTIZ \\ Department of Biology and Medical Laboratory Technology, Bronx Community College of the \\ City University of New York, Bronx, New York 10453, USA
}

(Received 7 January 1987)

Cell-free extracts of Ureaplasma urealyticum strains Pi and T960 (CX8) (serovars 6 and 8, respectively) metabolized inorganic pyrophosphate $\left(\mathbf{P P}_{\mathrm{i}}\right)$. The inorganic pyrophosphatase (PPase) activity was greatest with $\mathrm{Mg}^{2+}$ as cofactor, but $\mathrm{Mn}^{2+}$ acted as a poor substitute. The PPases of the two serovars differed electrophoretically. Although the highest PPase activity was obtained using $\mathrm{PP}_{i}$ as substrate, the enzyme could also utilize to a lesser degree both tripolyphosphate and trimetaphosphate. No activity was observed against $\beta$-glycerophosphate, naphthyl phosphates, glucose 6-phosphate, fructose 6-phosphate, fructose 1,6-bisphosphate, thiamin pyrophosphate, phosphoribosylpyrophosphate, ADP or ATP. Acid- and alkalinephosphatase activities were observed with naphthyl phosphates as substrates, but they did not have the same electrophoretic mobility on gels as the PPase activity. U. urealyticum PPase was inhibited by oxidized glutathione, 1-ethyl-3-(3-dimethylaminopropyl)carbodiimide, phenylglyoxal, $p$-chloromercuribenzoic acid, $\mathrm{Mn}^{2+}, \mathrm{Zn}^{2+}$ and $\mathrm{Ca}^{2+}$. Neither reduced glutathione, Lcysteine nor $\mathrm{Co}^{2+}$ enhanced activity. $\mathrm{PP}_{\mathrm{i}}$ can act as a substrate or regulator of certain metabolic reactions, and $\mathrm{PP}_{\mathrm{i}}$ metabolism can function in bacterial bioenergetics; its role in ureaplasmas is presently unclear.

\section{INTRODUCTION}

Although thirty years have passed since the identification of Ureaplasma urealyticum (Shepard et al., 1974), relatively little is known about its metabolism and energy generating pathways (Pollack, 1979, 1986; Shepard \& Masover, 1979), mainly because of poorly defined growth requirements and consequent low cell yield in culture. These mollicutes are one of the smallest cellular forms known, surviving with an extremely small genome (Razin, 1985) and limited metabolic capacity (Pollack, 1986). As such, ureaplasmas can be useful research tools for identifying basic biochemical activities conserved in nature, and indicating the bare essentials for cell survival.

Urease, which appears to be the most abundant protein in crude cell-free extracts of $U$. urealyticum, has been partially characterized (Eng et al., 1986). However, the role of urea hydrolysis in ureaplasma survival is still not clear. The most recent data suggest that ammonia diffusion subsequent to urea hydrolysis may be responsible for establishing a chemical potential across the ureaplasma membrane, thereby driving ATP formation (Romano et al., 1980, 1986). While ureaplasmas are nonglycolytic organisms (Shepard \& Masover, 1979), they have some enzymes of the glycolytic pathway (Cocks et al., 1985), and, therefore, may have the potential to form pyruvate from other substrates. Although they have many of the enzymes for pentose

Abbreviations: ACP, acid phosphatase; ALP, alkaline phosphatase: PPase, inorganic pyrophosphatase; EDAC, 1-ethyl-3-(3-dimethylaminopropyl)carbodiimide: NEM, N-ethyl-maleimide; PCMB, $p$-chloromercuribenzoic acid; TNBS, 2,4,6-trinitrobenzenesulphonic acid. 
phosphate metabolism (Cocks et al., 1985), the importance of this pathway in ureaplasmas is still not clear (Pollack, 1986). U. urealyticum does not metabolize arginine, unlike some other nonfermentative mollicutes (Shepard \& Masover, 1979). Enzymes of purine metabolism have been identified in $U$. urealyticum extracts (Cocks et al., 1985; Davis et al., 1984), so the possibility exists for energy conservation through the pathways of purine salvage. The presence of a complete tricarboxylic acid cycle and a cytochrome-containing electron transport system has not been shown (Pollack, 1979, 1986). We have been evaluating enzyme activities in cell-free extracts of ureaplasmas in an attempt to identify the presence of other pathways that may play an important role in the pathogen's metabolism.

Inorganic pyrophosphate $\left(\mathrm{PP}_{\mathrm{i}}\right)$ metabolism and the roles of inorganic pyrophosphatases (PPases) (EC 3.6.1.1) in microbes have been reviewed by Lahti (1983). PP $P_{i}$ may be a substrate, functioning as a source of energy while donating orthophosphate in ATP-sparing reactions (Wood, 1977). This requires different $\mathrm{PP}_{\mathrm{i}}$-dependent (ATP-sparing) enzymes which have been identified in a small number of microbes, including the mollicute Acholeplasma laidlawii (Pollack \& Williams, 1986; Tryon \& Pollack, 1984). In addition, the $\mathrm{PP}_{\mathrm{i}}$ in photosynthetic bacteria can serve as an energy donor in several energy-generating metabolic reactions (Keister \& Minton, 1971; Keister \& Raveed, 1974), and contribute to the establishment of an energylinked proton-motive force (Moyle et al., 1972). As a regulator, $\mathrm{PP}_{\mathrm{i}}$ tends to inhibit particular reactions; PPase could therefore limit inhibition by reducing the $\mathbf{P P}_{\mathrm{i}}$ level (Lahti, 1983).

Since $P P_{i}$ metabolism may be linked to bacterial bioenergetics, extracts of $U$. urealyticum were tested for PPase activity. Because the 14 serovars of $U$. urealyticum can apparently be separated into two distinct clusters (Razin et al., 1983; Robertson \& Stemke, 1982), extracts of two serovars ( 6 and 8 ) were compared as representatives of the different clusters.

\section{METHODS}

Chemicals. Unless noted otherwise, chemicals and enzymes were obtained from Sigma.

Cultures. Ureaplasma urealyticum strains Pi (serovar 6) and T960 (CX8) (serovar 8) were cultured in a modification of U17-B medium (Sayed \& Kenny, 1980; Shepard \& Lunceford, 1978). Basal medium contained (w/v): trypticase soy broth (BBL), $1.5 \%$; yeast extract (Difco), $0.2 \% ; \mathrm{NaCl}, 0.5 \% ; \mathrm{MgCl}_{2}, 0.05 \% ; \mathrm{MES}$ (Research Organics), $1.76 \%$; and phenol red (United States Biochemical), $0.001 \%$. The basal medium was brought to $\mathrm{pH} 6.0$, clarified by filtration $(0.2 \mu \mathrm{m})$, and sterilized by autoclaving $\left(121{ }^{\circ} \mathrm{C}, 15 \mathrm{~min}\right)$. Supplement for the basal medium contained $\gamma$-globulin-free horse serum (Gibco Laboratories, Life Technologies Inc.), $1.0 \%$ (v/v); CVA enrichment (Gibco), 0.25\% (v/v); urea (ultra-pure, Schwarz-Mann Biotech), $30 \mathrm{~mm}$; sodium sulphite, $1.0 \mathrm{~mm}$; and penicillin G, $10 \mathrm{U} \mathrm{ml}^{-1}$. Supplement was clarified by sterile filtration $(0.2 \mu \mathrm{m})$ and then added to the cooled sterile basal medium. Cultures were inoculated $(1: 1000)$ with an exponential phase culture and incubated for $22-24 \mathrm{~h}$ at $37^{\circ} \mathrm{C}$. This procedure produced a colour changing unit titre (Rodwell \& Whitcomb, 1983) of $10^{6}-10^{7}$.

Preparation of cell-free extract. A modification of the procedure of O'Brien et al. (1983) was used. Cells in exponential growth were collected by centrifugation $\left(20000 \mathrm{~g}, 45 \mathrm{~min}, 4^{\circ} \mathrm{C}\right)$, washed twice in buffered saline $(0 \cdot 25$ $\mathrm{M}-\mathrm{NaCl} ; 0.01 \mathrm{mM}-\mathrm{MgCl}_{2} ; 0.02 \mathrm{M}$-Tris, $\left.\mathrm{pH} 7.5\right)$, suspended in hypotonic extraction buffer $(0.01 \mathrm{M}$-Tris, $0.001 \mathrm{M}$ EDTA, $0.1 \%$ Triton X-100, $\mathrm{pH} 7.4)$, subjected to freeze-thaw $\left(-80^{\circ} \mathrm{C}\right.$ to $37^{\circ} \mathrm{C}$ ), and sonicated at $200 \mathrm{~W}$ for $10 \mathrm{~min}$ (ten cycles of $1 \mathrm{~min}$ sonication followed by $1 \mathrm{~min}$ cooling, all on ice). The sonicate was centrifuged $\left(37000 \mathrm{~g}, 45 \mathrm{~min}, 4^{\circ} \mathrm{C}\right.$ ) and the supernatant extract was concentrated using an ultrafiltration system (Centricon 10 , Amicon). The concentrate was diluted with an equal volume of sample buffer $(0.06 \mathrm{M}$-Tris, $0.28 \%$ Triton $\mathrm{X}$ $100,20 \%$ glycerol, $\mathrm{pH} 6 \cdot 8$ ). The final protein concentration was determined by the technique of Bradford (1976) using a Bio-Rad protein assay kit, with bovine serum albumin as the standard. Samples of extract were stored at $-80^{\circ} \mathrm{C}$ until used.

Electrophoresis of cell-free extracts. Proteins in the cell-free extract were electrophoretically separated on polyacrylamide gels to provide partial purification of the enzyme to be assayed. Sample wells were loaded with $30 \mu \mathrm{g}$ extract protein. Electrophoresis was performed using a modification of the Laemmli discontinuous buffer system (Hames, 1981), substituting Triton X-100 (0.1\%) for SDS. An LKB 2001 vertical electrophoresis unit was used with $1.5 \mathrm{~mm}$ thick gel slabs prepared with a $7.0 \%$ acrylamide resolving gel and a $3.75 \%$ acrylamide stacking gel. Acrylaide (FMC Corp.) was used as the crosslinker (acrylamide: Acrylaide, 32:1), and gels were cast on GelBond (FMC Corp.) to facilitate handling of the gel for the enzyme assays. Electrophoresis was carried out at $100 \mathrm{~V}$ per gel using an LKB 2002 power supply, with cooling to $15-18^{\circ} \mathrm{C}$. Electrophoresis was stopped when the tracking dye was $1 \mathrm{~cm}$ from the bottom of the gel (approx. $5 \mathrm{~h}$ ). Gels were rinsed with reagent-grade water before use in assays. 
Assays for PPase activity. After electrophoresis, gels were cut into five to seven test strips for enzyme assays. The assay system for PPase activity was a post-incubation coupling technique (Harris \& Hopkinson, 1976) utilizing an assay mixture of $0.025 \mathrm{M}-$ Tris, $5.0 \mathrm{~mm}-\mathrm{PP}_{\mathrm{i}}, \mathrm{pH} \mathrm{7.8} ; 5.0 \mathrm{mM}^{-\mathrm{MgCl}_{2}}$; and $1 \%$ Noble agar. Gel test strips were overlayed with assay mixture and incubated at $37^{\circ} \mathrm{C}$. After $45 \mathrm{~min}$ the overlay was removed. The test strip was rinsed with water and immersed in developer $\left(1.25 \%, \mathrm{w} / \mathrm{v}\right.$, molybdic acid in $2 \mathrm{M}-\mathrm{H}_{2} \mathrm{SO}_{4} ; 5 \%, \mathrm{w} / \mathrm{v}, \mathrm{L}$-ascorbic acid added just before application) in the dark to indicate the sites of phosphate release (stained areas appeared in approx. $15 \mathrm{~min})$.

Yeast PPase $(0 \cdot 2 \mathrm{U})$ and concentrated culture medium ( $30 \mu \mathrm{g}$ protein) were run as controls. Substrates $(5 \cdot 0 \mathrm{mM})$ tested in the assay incubation mix included: tetrasodium pyrophosphate ( $P P_{i}$, J. T. Baker Co.), pentasodium tripolyphosphate, trisodium trimetaphosphate, phosphoribosylpyrophosphate (PRPP), thiamin pyrophosphate (TPP), ATP, ADP, fructose 1,6-bisphosphate, $\beta$-glycerophosphate, $\alpha$ - and $\beta$-naphthyl phosphates, glucose 6phosphate and fructose 6-phosphate.

Divalent cations $\left(\mathrm{Mn}^{2+}, \mathrm{Ca}^{2+}, \mathrm{Cd}^{2+}, \mathrm{Co}^{2+}, \mathrm{Cu}^{2+}, \mathrm{Zn}^{2+}\right)\left(\mathrm{CdCl}_{2}\right.$ and $\mathrm{ZnCl}_{2}$ from Fisher Scientific Co. $)$ were evaluated as cofactors for $U$. urealyticum PPase. The cations were tested individually both as a replacement for $\mathrm{Mg}^{2+}$ and as ions competing with $\mathbf{M g}^{2+}$.

PPase activity in the crude cell-free extracts was also assayed using a pyrophosphate assay reagent (Sigma), following the manufacturer's instructions. The procedure was used to evaluate $\mathrm{PP}_{\mathrm{i}}$ hydrolysis during an $8 \mathrm{~min}$ period, samples with extract $\left(95 \mu \mathrm{g}\right.$ extract protein, per $\mathrm{ml} \mathrm{PP} \mathrm{P}_{\mathrm{i}}$ standard) being compared to others containing an equal volume of sample buffer.

Inhibition and activation of PPase activity. PPase activity was also evaluated for the effects of $\mathrm{NH}_{4}^{+}(5 \cdot 0 \mathrm{mM}, 50 \cdot 0$ $\mathrm{mM}$ ), $N$-ethylmaleimide (NEM, 0.5 mM), 1-ethyl-3-(3-dimethylaminopropyl)carbodiimide (EDAC, 10.0 mM), oxidized glutathione (1.0 mM), reduced glutathione ( $1.0 \mathrm{mM})$, sodium fluoride $(20.0 \mathrm{~mm}$, Fisher Scientific Co. $), p$ chloromercuribenzoic acid (PCMB, 0.5 mM), phenylglyoxal (10.0 mM), 2,4,6-trinitrobenzenesulphonic acid (TNBS, $0.5 \mathrm{mM})$, and L-cysteine $(0.5 \mathrm{~mm})$.

Assays for acid phosphatase $(A C P)$ and alkaline phosphatase $(A L P)$ activities. Partially purified enzyme was used in simultaneous capture techniques to assay for ACP and ALP activities (Harris \& Hopkinson, 1976). The ACP assay mixture consisted of $0.05 \mathrm{M}$-citrate buffer, $\mathrm{pH} 4.5 ; 0 \cdot 1 \%$ substrate $; 0 \cdot 12 \% \mathrm{MgSO}_{4} .7 \mathrm{H}_{2} \mathrm{O} ;$ and $0 \cdot 1 \%$ Fast $\mathrm{Blue}$ BB or RR. The ALP assay mixture contained $0.06 \mathrm{M}$-borate buffer, $\mathrm{pH} 9 \cdot 7 ; 0.05 \%$ substrate; $0.12 \% \mathrm{MgSO}_{4}$. $7 \mathrm{H}_{2} \mathrm{O}$; and $0.05 \%$ Fast Blue BB salt. Both enzyme activities were assayed with $\alpha$-naphthyl phosphate and $\beta$ naphthyl phosphate as substrate, and with $80 \mu \mathrm{g}$ extract protein. $\beta$-Glycerophosphate and $\mathrm{PP}_{\mathrm{i}}$ were tested as $\mathrm{ACP}$ or ALP substrates by using them with the PPase post-incubation assay technique at $\mathrm{pH} 4 \cdot 5$ and $9 \cdot 7$. Potato ACP $(0.36 \mathrm{U})$ and bovine ALP $(0.5 \mathrm{U})$ were used as positive controls in these assays.

\section{RESULTS}

PPase activity in crude cell-free extract

Crude extracts of $U$. urealyticum actively hydrolysed $\mathrm{PP}_{\mathrm{i}}$. Under these assay conditions, the crude extract hydrolysed an average of $7.5 \times 10^{-4} \mu \mathrm{mol} \mathrm{PP}_{\mathrm{i}} \min ^{-1}(\mu \mathrm{g} \text { extract protein })^{-1}$, during the $8 \mathrm{~min}$ assay period.

\section{Activity of partially purified PPase}

PPase activity was found in extracts of both the $U$. urealyticum serovars tested (Fig. 1). Similar results were obtained with all batches tested (thirteen of serovar 8 and five of serovar 6 ). Enzyme activity did not vary detectably in the $\mathrm{pH}$ range $6 \cdot 2$ to 8.0 . No PPase activity was found in the culture medium. Comparison of the activity sites on the gel indicated that the PPase of serovar 8 exhibited a relative mobility of $1 \cdot 28$, while that of serovar 6 had a relative mobility of 0.85 . The greatest enzyme activity was obtained with $\mathrm{Mg}^{2+}$ as cofactor. $\mathrm{Mn}^{2+}(5.0 \mathrm{mM})$ was a poor substitute for $\mathrm{Mg}^{2+} . \mathrm{Ca}^{2+}, \mathrm{Cd}^{2+}, \mathrm{Co}^{2+}, \mathrm{Cu}^{2+}$, or $\mathrm{Zn}^{2+}(5 \cdot 0 \mathrm{mM})$ could not replace $\mathrm{Mg}^{2+}$.

Tripolyphosphate could be used as substrate by extract PPase, but was hydrolysed less rapidly than $\mathrm{PP}_{\mathrm{i}}$. Trimetaphosphate was a poorer substrate than polyphosphate. Organic pyrophosphates, such as TPP, ATP and ADP, could not act as substrates, although extremely weak PPase activity was obtained with PRPP. The latter was most probably due to contaminating $\mathbf{P P}_{\mathrm{i}}$ released by the relatively unstable PRPP.

Since other phosphatase activities have been reported in ureaplasmas (Black, 1973), enzymes in the gel test strips were assayed with a variety of other phosphatase substrates, including $\alpha$ naphthyl phosphate, $\beta$-naphthyl phosphate, $\beta$-glycerophosphate, fructose 1,6 -bisphosphate, fructose 6-phosphate and glucose 6-phosphate. Extracts of both serovars 6 and 8 possessed ACP 


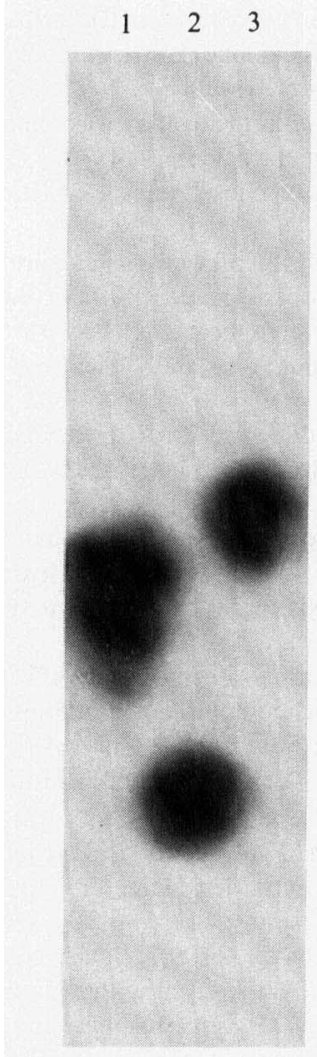

Fig. 1

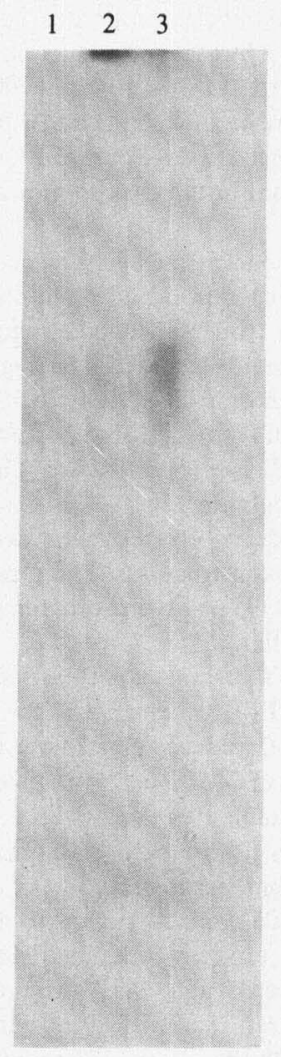

Fig. 2

Fig. 1. Zymogram indicating PPase activity in extracts from $U$. urealyticum. Lane 1, yeast PPase, $0 \cdot 2$ $\mathrm{U}$; lane 2, U. urealyticum strain T960 (CX8) (serovar 8); lane 3, U. urealyticum strain Pi (serovar 6). If the yeast PPase is assigned an electrophoretic mobility of $1 \cdot 0$, the relative mobilities of strains T 960 and $\mathrm{Pi}$ are $1 \cdot 28$ and $0 \cdot 85$, respectively.

Fig. 2. Zymogram showing ACP activity in extracts from $U$. urealyticum. Lane 1, potato ACP, $0.36 \mathrm{U}$; lane 2,U. urealyticum strain T960 (CX8) (serovar 8); lane 3, U. urealyticum strain Pi (serovar 6).

activity only against the naphthyl phosphates (Fig. 2). Weak ALP activity in the extracts was observed with $\alpha$-naphthyl phosphate only. ACP activity had a different electrophoretic mobility from the $U$. urealyticum PPase activity of either extract; similar results were obtained with ALP, indicating that the PPase and ACP/ALP are different. $\mathrm{PP}_{\mathrm{i}}$ was not hydrolysed by the extract ACP or ALP.

\section{Inhibition of PPase activity}

Several different ions $(5.0 \mathrm{~mm})$ inhibited the $U$. urealyticum extract PPase activity when incubated with the enzyme for 15 min prior to the addition of assay mix with $\mathrm{Mg}^{2+} . \mathrm{Mn}^{2+}$ and $\mathrm{Zn}^{2+}$ resulted in almost complete inhibition of PPase activity, while the presence of $\mathrm{Ca}^{2+}$ resulted in only moderate inhibition. $\mathrm{Cd}^{2+}, \mathrm{Co}^{2+}$ and $\mathrm{Cu}^{2+}$ had no measurable inhibitory effect on the enzyme, while $\mathrm{NH}_{4}^{+}(5-50 \mathrm{mM})$ caused little or no inhibition.

The effect of known PPase inhibitors on yeast and $U$. urealyticum extract PPase activity was tested. NEM $(0.5 \mathrm{mM})$ and TNBS $(0.5 \mathrm{~mm})$ had no effect on either PPase activity. NaF $(20.0 \mathrm{mM})$ inhibited yeast PPase, but had no effect on extract activity. Phenylglyoxal (10.0 mM), EDAC $(10.0 \mathrm{mM})$, PCMB $(0.5 \mathrm{mM})$, and oxidized glutathione $(1.0 \mathrm{mM})$ each inhibited enzyme activity of both $U$. urealyticum and yeast. These inhibitors were most effective when preincubated with the 
gel strips prior to application of the assay mixture, rather than being added with the assay mixture at the time of incubation.

\section{Activation of PPase activity}

Neither L-cysteine $(0.5 \mathrm{~mm})$ nor reduced glutathione $(1.0 \mathrm{~mm})$ significantly activated $U$. urealyticum extract or yeast PPase activity, nor did $\mathrm{Co}^{2+}$ or $\mathrm{Cu}^{2+}$ enhance activity when added with the assay mix.

\section{DISCUSSION}

The electrophoretic technique and assay procedure used in this investigation overcame a significant problem in studying ureaplasma enzymes, i.e. low yield of cell-free extract from large volumes of culture (O'Brien \& Barile, 1983). By separating and concentrating proteins, the electrophoretic technique permitted the study of enzyme activity in relatively small amounts of crude cell-free extract.

O'Brien et al. $(1981,1983)$ have reported the presence of PPase in each of 15 Mycoplasma species tested, and in three of five Acholeplasma species. They did not find the enzyme activity in $A$. laidlawii, $A$. axanthum, or $U$. urealyticum. Using slightly different methods we have found that extracts of $U$. urealyticum possess PPase activity, distinct from ACP or ALP activity. The extract was very active in hydrolysing $\mathrm{PP}_{\mathrm{i}}$ in the presence of $\mathrm{Mg}^{2+}$; less activity was obtained with tripolyphosphate or trimetaphosphate as substrate, and these activities may have been due in part to $P P_{i}$ contamination of the substrates. The enzyme did not hydrolyse organic pyrophosphates, indicating that $\mathrm{MgPP}_{\mathrm{i}}$ is the probable substrate for the U. urealyticum PPase.

Comparison of the relative mobilities of PPases from $U$. urealyticum serovars 6 and 8 indicated that the enzymes are different. Since these two serovars are in the two different serovar clusters of $U$. urealyticum, the PPase activity could prove to be a useful marker for distinguishing the two clusters; however, this requires further study.

The optimum cofactor for the $U$. urealyticum PPase in the assay procedure (pH 7.8) is $\mathbf{M g}^{2+}$, suggesting a greater similarity to the PPases of Streptococcus and Lactobacillus (Lahti, 1983; Lahti \& Niemi, 1981) than to the PPase of Bacillus subtilis (Tono \& Kornberg, 1967) for which the optimum cofactor is $\mathrm{Mn}^{2+}$, a cation that was not a cofactor for the enzyme of Streptococcus faecalis (Lahti \& Niemi, 1981), and gave only slight activity with $U$. urealyticum PPase. $\mathrm{Co}^{2+}$, which is a weak cofactor for $S$. faecalis PPase (Lahti \& Niemi, 1981), did not support activity of the $U$. urealyticum enzyme. However, we evaluated the cations at a single concentration ( $5.0 \mathrm{mM}$ ), so the possibility remains that $U$. urealyticum PPase may be functional with other ions at different concentrations and/or a different $\mathrm{pH}$, as Oginsky \& Rumbaugh (1955) reported for $\mathrm{Co}^{2+}$ and the PPase of $S$. faecalis.

The inhibition of extract PPase activity by $\mathrm{Mn}^{2+}$ and $\mathrm{Zn}^{2+}$ may account in part for the growth inhibition observed when $\mathrm{Mn}^{2+}$ is present in culture medium (Robertson \& Chen, 1984), and could explain the decrease in isolations of ureaplasmas from semen when the semen $\mathrm{Zn}^{2+}$ levels increase during prostatitis (Weidner et al., 1985).

In his review, Lahti (1983) notes that the PPase of Streptococcus is reportedly activated by reduced glutathione and thiol compounds, and inactivated by oxidized glutathione and thiol inhibitors. The measured effect, however, depended upon the form of PPase studied, i.e. the high activity form associated with extracts of exponential phase cultures, or the low activity form found in older cultures. If the $U$. urealyticum PPase was similar, activators would have had little effect and thiol inhibitors a large effect on the enzyme activity, since the extract was prepared from cells in the exponential phase of growth. This is consistent with our observations that oxidized glutathione and PCMB were inhibitory, while reduced glutathione and L-cysteine produced little or no activation.

That PPase is present in organisms with such a small genome (i.e. mycoplasmas and ureaplasmas) may indicate that $\mathrm{PP}_{\mathrm{i}}$ hydrolysis is a basic activity in the cell. Our studies do not identify the role of $\mathrm{PP}_{i}$ hydrolysis in ureaplasmas, for which there are several possibilities. The presence of $\mathrm{PP}_{\mathrm{i}}$-dependent phosphofructokinase in $A$. laidlawii $\mathrm{B}-\mathrm{PG} 9$ suggests that $\mathrm{PP}_{\mathrm{i}}$ 
utilization in this organism is an energy-conserving (ATP-sparing) process (Pollack \& Williams, 1986). Tryon \& Pollack (1984) speculated that $\mathrm{PP}_{i}$ may be more available as a substrate in $A$. laidlawii $\mathrm{B}$ because this strain apparently lacks significant PPase activity. However, PPase was found in the majority of Mycoplasma and Acholeplasma species tested by O'Brien et al. (1981), and in the ureaplasmas tested here, suggesting that PPase-dependent $\mathbf{P P}_{\mathrm{i}}$ hydrolysis in mollicutes may not function primarily to spare ATP hydrolysis.

Since Romano et al. $(1980,1986)$ have suggested that orthophosphate concentration influences urea hydrolysis which in turn affects ATP synthesis by ureaplasmas, it may be that PPase helps to regulate phosphate levels in these organisms thereby optimizing urease activity and subsequent ATP synthesis. PPase-regulated phosphate exchange across chromatophore membranes has been reported as a dark reaction of Rhodospirillum (De Meis et al., 1986). In fact, PPase has been extensively studied with Rhodospirillum, an unusual prokaryote containing chromatophores in which $\mathrm{PP}_{\mathrm{i}}$ metabolism is a significant part of the energy generating

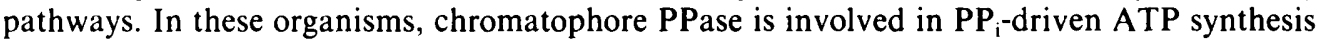
from ADP and $P_{i}$ (Keister \& Minton, 1971), $P_{i}-P_{P}$ exchange (Keister \& Raveed, 1974), proton translocation across the membrane (Moyle et al., 1972), and several other energy-linked reactions (cited in De Meis et al., 1986; Keister \& Raveed, 1974). The $\mathrm{H}^{+}$-translocating PPases of Rhodospirillum (Moyle et al., 1972) and oat root tonoplast vesicles (Wang et al., 1986) have been suggested as another source of proton motive force used for energy requiring processes. While energy generating mechanisms involving $\mathrm{PP}_{\mathrm{i}}$ hydrolysis may function in $U$. urealyticum, this possibility needs confirmation.

This work was supported by the Minority Biomedical Research Support Program grant RR-08174 from the National Institutes of Health. We thank Janet Robertson for providing lyophilized U. urealyticum cultures.

\section{REFERENCES}

Black F. T. (1973). Phosphatase activity in Tmycoplasmas. International Journal of Systematic Bacteriology 23, 65-66.

BRADFORD, M. M. (1976). A rapid and sensitive method for the quantitation of microgram quantities of protein utilizing the principle of proteindye binding. Analytical Biochemistry 72, 248-254.

Cocks, B. G., Brake, F. A., Mitchell, A. \& Finch, L. R. (1985). Enzymes of intermediary carbohydrate metabolism in Ureaplasma urealyticum and Mycoplasma mycoides subsp. mycoides. Journal of General Microbiology 131, 2129-2135.

Davis, J. W., Nelson, P. \& Ranglin, R. (1984). Enzyme activities contributing to hypoxanthine production in Ureaplasma. Israel Journal of Medical Sciences 20, 946-949.

De Meis, L., Behrens, M. I., Celis, H. Romero, I., Gomez Puyou, M. T. \& Gomez Puyou, A. (1986). Orthophosphate-pyrophosphate exchange catalyzed by soluble and membrane-bound inorganic pyrophosphatases. Role of $\mathrm{H}^{+}$gradient. European Journal of Biochemistry 158, 149-157.

Eng, H., Robertson, J. A. \& Stemke, G. W. (1986). Properties of urease from Ureaplasma urealyticum. Kinetics, molecular weight, and demonstration of multiple enzyme isoelectric point forms. Canadian Journal of Microbiology 32, 487-493.

Hames, B. D. (1981). An introduction to polyacrylamide gel electrophoresis. In Gel Electrophoresis of Proteins: A Practical Approach, pp. 1-91. Edited by B. D. Hames \& D. Rickwood. Washington, DC: IRL Press.

HARRIS, H. \& HoPKINSON, D. A. (1976). Handbook of
Enzyme Electrophoresis in Human Genetics. Amsterdam: North-Holland Publishing.

KeISTER, D. L. \& MinTon, N. J. (1971). Energy-linked reactions in photosynthetic bacteria. VI. $\mathbf{P}_{\mathrm{i}}-\mathbf{P P}$, exchange in Rhodospirillum rubrum. Journal of Biological Chemistry 249, 6454-6458.

KeISTER, D. L. \& RaveED, N. J. (1974). Energy-linked reactions in photosynthetic bacteria. IX. Inorganic pyrophosphate-driven ATP synthesis in Rhodospirillum rubrum. Archives of Biochemistry and Biophysics 147, 330-338.

LAHTI, R. (1983). Microbial inorganic pyrophosphatases. Microbiological Reviews 47, 169-179.

LAhTI, R. \& Nieml, T. (1981). Purification and some properties of inorganic pyrophosphatase from Streptococcus faecalis. Journal of Biochemistry 90, 79-85.

Moyle, J., Mitchell, R. \& Mitchell, P. (1972). Proton translocating pyrophosphatase of Rhodospirillum rubrum. FEBS Letters 23, 233-236.

O'Brien, S. J. \& Barile, M. F. (1983). Isozyme resolution in mycoplasmas. In Methods in Mycoplasmology, vol. 1, pp. 391-396. Edited by S. Razin \& J. G. Tully. New York: Academic Press.

O'Brien, S. J., Simonson, J. M., GrabowsKi, M. W. \& Barile, M. F. (1981). Analysis of multiple isoenzyme expression among twenty-two species of Mycoplasma and Acholeplasma. Journal of Bacterio$\log y$ 146, 222-232.

O'Brien, S. J., Simonson, J. M., Razin, S. \& Barile, M. F. (1983). On the distribution and characteristics of isozyme expression in Mycoplasma, Acholeplasma, and Ureaplasma species. Yale Journal of Biology and Medicine 56, 701-708.

Oginsky, E. L. \& Rumbaugh, H. L. (1955). A cobalt- 
activated bacterial pyrophosphatase. Journal of Bacteriology 70, 92-98.

Pollack, J. D. (1979). Respiratory pathways and energy-yielding mechanisms. In The Mycoplasmas, vol. 1, Cell Biology, pp. 187-211. Edited by M. F. Barile \& S. Razin. New York: Academic Press.

Pollack, J. D. (1986). Metabolic distinctiveness of ureaplasmas. Pediatric Infectious Disease 5, S305S307.

Pollack, J. D. \& Williams, M. V. (1986). PP - $^{-}$ dependent phosphofructotransferase (phosphofructokinase) activity in the Mollicutes (Mycoplasma) Acholeplasma laidlawii. Journal of Bacteriology 165, 53-60.

RAZIN, S. (1985). Molecular biology and genetics of mycoplasmas (Mollicutes). Microbiological Reviews 49, 419-455.

Razin, S., Harasawa, R. \& Barile, M. F. (1983). Cleavage patterns of the mycoplasma chromosome, obtained by using restriction endonucleases, as indicators of genetic relatedness among strains. International Journal of Systematic Bacteriology 33, 201-206.

Robertson, J. A. \& Chen, M. H. (1984). Effects of manganese on the growth and morphology of Ureaplasma urealyticum. Journal of Clinical Microbiology 19, 857-864.

Robertson, J. A. \& Stemke, G. W. (1982). Expanded serotyping scheme for Ureaplasma urealyticum strains isolated from humans. Journal of Clinical Microbiology 15, 873-878.

RODWELL, A. W. \& Whitcomb, R. F. (1983). Methods of direct and indirect measurement of mycoplasma growth. In Methods in Mycoplasmology, vol. 1, pp. 185-196. Edited by S. Razin \& J. G. Tully. New York: Academic Press.

Romano, N., Tolone, G., Ajello, F. \& lalicata, R. (1980). Adenosine 5'-triphosphate synthesis induced by urea hydrolysis in Ureaplasma urealyticum. Journal of Bacteriology 144, 830-832.

Romano, N., Lalicata, R. \& Alesi, D. R. (1986). Energy production in Ureaplasma urealyticum. Pediatric Infectious Disease 5, S308-S312.
SAYED, I. A. \& KenNy, G. E. (1980). Comparison of the proteins and polypeptides of the eight serotypes of Ureaplasma urealyticum by isoelectric focusing and sodium dodecyl sulfate-polyacrylamide gel electrophoresis. International Journal of Systematic Bacteriology 30, 33-41.

SHEPARD, M. C. \& LUNCEFoRd, C. D. (1978). Serological typing of Ureaplasma urealyticum isolates from urethritis patients by an agar growth inhibition method. Journal of Clinical Microbiology 8, 566-574.

ShePard, M. C. \& Masover, G. K. (1979). Special features of ureaplasmas. In The Mycoplasmas, vol. 1, Cell Biology, pp. 451-494. Edited by M. F. Barile \& S. Razin. New York: Academic Press.

Shepard, M. C., Lunceford, C. D., Ford, D. K., Purcell, F., TAYlor-Robinson, D., Razin, S. \& BLACK, F. T. (1974). Ureaplasma urealyticum gen. nov., sp. nov.: proposed nomenclature for the human T (T-strain) mycoplasma. International Journal of Systematic Bacteriology 24, 160-171.

TONo, H. \& KorNBERG, A. (1967). Biochemical studies of bacterial sporulation. III. Inorganic pyrophosphatase of vegetative cells and spores of Bacillus subtilis. Journal of Biological Chemistry 242, 2375-2382.

Tryon, V. V. \& Pollack, J. D. (1984). Purine metabolism in Acholeplasma laidlawii $\mathbf{B}$ : novel $\mathbf{P P}_{\mathbf{i}}$ dependent nucleoside kinase activity. Journal of Bacteriology 159, 265-270.

Wang, Y., Leigh, R. A., KaEstNer, K. H. \& Sze, H. (1986). Electrogenic $\mathrm{H}^{+}$-pumping pyrophosphatase in tonoplast vesicles of oat roots. Plant Physiology 81 , 497-502.

Weidner, W., Krause, W., Schiefer, H. G., BrunNER, H. \& FRIEDRICH, H. J. (1985). Ureaplasmal infections of the male urogenital tract, in particular prostatitis, and semen quality. Urologia internationalis 40, 5-9.

WooD. H. G. (1977). Some reactions in which inorganic pyrophosphate replaces ATP and serves as a source of energy. Federation Proceedings 36, 2197 2205. 